\title{
SISTEM INFORMASI PERSEDIAAN OBAT PADA PUSKESMAS SUNGAI SEMBILAN BERBASIS WEB
}

\author{
Putri Yunita ${ }^{1}$, Dwi Maya Sari ${ }^{2}$ \\ ${ }^{1,2}$ Sekolah Tinggi Manajemen Informatika \& Komputer (STMIK) Dumai \\ Jalan Utama Karya Bukit Batrem Dumai-Riau Kode Pos 28811 \\ Email : yunita.santoso3710@gmail.com ${ }^{1}$, dwimayasari@gmail.com ${ }^{2}$
}

\begin{abstract}
ABSTRAK
Obat tidak terlepas dari dunia kesehatan. Puskesmas Sungai Sembilan merupakan instansi yang bergerak dibidang kesehatan yang menggunakan obat. Aktivitas yang sering dilakukan di apotek Puskesmas Sungai Sembilan berupa pencatatan obat masuk dan obat keluar. Dalam kegiatan tersebut terdapat kelemahan yaitu, pencatatan obat masuk dan obat keluar masih menggunakan buku catatan sehingga membutuhkan waktu yang relatif lama dalam pencatatan obat. Lambatnya dalam pencarian data obat untuk melihat ketersediaan obat, pembuatan laporan data obat. Belum adanya laporan yang memberikan informasi obat yang kadarluarsa. Untuk menyelesaikan masalah permasalahan yang terjadi diperlukan sebuah sistem informasi persediaan obat. Sistem ini memudahkan apoteker dalam proses pencatatan data obat, proses pencarian data obat lebih cepat untuk mengetahui stok obat, memudahkan apoteker dalam merekap data obat, memperoleh informasi kadarluarsa obat, sistem ini akan dirancang menggunakan bahasa pemograman PHP yang nantinya dapat diakses secara online.
\end{abstract}

Kata kunci : Sistem Informasi, Obat, Pemograman PHP

\section{ABSTRACT}

Medicine is inseparable from the world of health. Sungai Sembilan Public Health Center is an agency engaged in health that uses drugs. Activities that are often carried out at the pharmacy of Sungai Sembilan Community Health Center include recording incoming and outgoing medicines. In these activities there are weaknesses, namely recording drugs in and out drugs are still using a notebook so it requires a relatively long time in recording drugs. The slowness in searching drug data to see the availability of drugs, making drug data reports. There are no reports that provide expired drug information. To solve the problems that occur, a drug supply information system is needed. This system facilitates pharmacists in the process of recording incoming and outgoing drugs, the process of finding drug data faster to find out drug stocks, facilitating pharmacists in making drug data reports, obtaining information on drug expiration, this system will be designed using the PHP programming language which will later be accessible online.

Keywords : Information Systems, Drug Making, PHP Programming

\section{PENDAHULUAN}

Obat terbagi menjadi dua kategori yaitu obat paten dan obat generik. Obat paten adalah obat jadi dengan nama dagang yang sudah terdaftar dan hnaya diproduksi oleh industri yang memiliki hak paten tersebut dengan masa berlaku selama 20 tahun. Selama kurun waktu tersebut perusahaan lain tidak dapat diperkenankan untuk memproduksi obat serupa kecuali memiliki perjanjian khusus dengan pemilik paten. Setelah habis masa patennya obat tersebut dapat diproduksi oleh semua industri farmasi. Obat inilah yang dinamakan obat genetik. 
IN F ORMA TIK

Jurnal Informatika, Manajemen dan Komputer, Vol. 12 No. 1, Mei 2020

eISSN : 2580-3042

pISSN : 1979-0694

Obat tidak terlepas dari dunia kesehatan. Salah satunya Puskesmas Sungai Sembilan merupakan instansi yang bergerak dibidang kesehatan yang menggunkana obat. Puskesmas Sungai Sembilan memiliki kegiatan dalam hal perawatan dan pengobatan pasien. Dalam mendukung kegiatan tersebut, Puskesmas Sungai Sembilan dilengkapi dengan sebuah apotek. Dimana apotek tersebut merupakan tempat untuk pengambilan obat pasien yang berobat di Puskesmas Sungai Sembilan.

Aktivitas yang sering dilakukan di apotek Puskesmas Sungai Sembilan berupa pencatatan obat masuk dan obat keluar. Dalam kegiatan tersebut terdapat kelemahan yaitu, pencatatan obat masuk dan obat keluar masih menggunakan buku catatan. Kegiatan ini kurang efektif karena obat yang tersedia banyak sehingga memerlukan waktu yang relatif lama dalam pencatatan obat. Banyaknya data membuat bagian apotek lambat dalam melukan pencarian obat. Lambatnya dala pembuatan laporan data obat karena data yang tersedia belum terstruktur. Selain itu, belum adanya laporan yang memberka informasi obat yang telah kadaluarsa.

Maka untuk menyelasikan pemasalahan yang terjadi pada apotek Puskemas Sungai Sembilan diperlukan sebuah sistem nformasi persediaan obat. Dimana sistem ini memudahkan bagian apotek dalam proses pencarian obat masuk dan obat keluar, proses pencarian obat lebih cepat dan mudah mengetahui stok obat. Memudahkan bagian apotek dalam memperoleh informasi obat kadaluarsa yang diketahui dari validasi di sistem.

\section{a. Sistem}

sistem merupakan sekumpulan dari elemenelemen yang berinteraksi untuk mencapa suatu tujuan tertentu. Suatu sistem mempunyai maksud tertentu. (Jogiyanto, 2005:2)

\section{b. Informasi}

Informasi merupakan data yang telah terorgansir sehingga memberikan arti dan nilai kepada penerimanya. (Fanny Andalia, Eko Budi Setiawan, 2015)

\section{c. Persediaan}

Persediaan merupakan serangkaian kebijaksaan dan pengendalian yang memonitor tingkat persediaan dan menentukan tingkat persedian yang harus dijaga, kapan persediaan harus diisi, dan berapa besar pesanan yang harus dilakukan (Indrajit dan Djokopranoto, 2003).

Sistem ini bertujuan untuk memetapkan dan menjamin tersedianya sumber daya yang tepat dalam kuantitas tepat dan pada waktu yang tepat. (Elisawati \& Rianto Riduan S, 2019)

\section{d. Obat}

Obat dalam bahasa inggris disebut drug sedangkan dalam bahasa prancis disebut droque yang berarti rempah kering. Menurut bagian Farmakologi obat didefinisikan sebagai substansi yang digunakan untuk pencagahan, diagnosa dan pengonatan pada manusia maupun binatang. (Ariani, 2016:4)

\section{e. Bootsrap}

Menurut (Kaban, 2009:1) bootsrap merupakan sebuah framework CSS yang paling banyak diminati oleh para developer website. Class-class CSS dalam bootsrap sudah dibakukan sehingga pengerjaan sebuah project berbasis web menjadi semakin mudah dilakukan secara bersama-sama dalam sebuah tim. Kita dengan mudah dapat mendasain tampilan webtise yang responsift dengan menggunakan bootsrap. Responsif maksdunya adalah lebar halaman website akan disesuaikan otomatis perangkat berdasarkan perangkat yang digunakan untuk mengaksesnya. Baik itu ketika diakses menggunakan PC, lapotop, tablet ataupun smarthpone sehinggan website akan menyesuaikan degan lebar perangkat yang digunakan pengunjung.

\section{f. Hosting}

Hosting adalah tempat untuk menyimpan berkas halaman website yang telah anda buat agar bisa diakses secara online. Sebuah hosting terdiri dari sebuah server maupun gabungan beberapa server yang terhunung dengan jaringan internet berkecepatan tinggi. (Andi, 2014:232)

\section{METODOLOGI PENELITIAN}

Metode waterfall menurut sommerville (2003) adalah sebuah contoh dari proses perencanaan, dimana semua proses kegiatan harus direncanakan dan di jadwalkan sebelum dikerjakan. (Destiningrum \& Adrian, 2017)

Penjelasan kerangka penelitian sebagai berikut :

1. Mengidentifikasi Masalah

Pertama yang harus dilakukan adaah mengetahui permasalahan yang sedang dihadapi pada apotek Puskesmas Sungai Sembilan dalam mengelola persediaan obat 
IN F ORMA T I K A

Jurnal Informatika, Manajemen dan Komputer, Vol. 12 No. 1, Mei 2020

elSSN : 2580-3042

pISSN : 1979-0694

2. Mengumulkan Data

Tahap selanjutnya yang berhubungan dengan pengumpulan data sesuai dengan maslah apada objek penelitian. Adapun teknik pengumpulan data sebagai berikut :

a. Study Perpustakaan

Pada teknik ini dilakukannya pengumpulan data-data dan mempelajarinya yang baik berupa teori yang bersumber dari buku refensi dan junal ilmiah yang berhubungan dengan studi kasus.

b. Survei Lapangan

Dengan diadakannya survei ke objek peneliatian maka dengan mudah mendapatkan informasi yang dibutuhkan.

\section{Analisa Data}

Data obat yang telah dikumpulkan dari Puskesmas Sungai Sembilan akan dianalisa kemudian hasilnya digunakan untuk pembuatan perancangan sistem sesuai dengan kebutuhan

4. Perancangan Sistem

Perancangan sistem yang akan dibuat dengan menggunakan pemograman berbasis web sesuai dengan kebutuhan.

\section{Pembuatan Sistem}

Tahap ini dilakukan pembuatn sistem yang telah dirancang sebelumnya.

\section{Uji Coba}

Uji coba sistem akan dilakukan eksekusi sistem yang telah siap digunakan dengan menjalankannya. Kemudian melakukan perbaikan sistem jika ada terdapat kesalahanyang tidak sesuai dengan kebutuhan objek penelitian dalam analisa sistemnya serta menyesuaikan dengan kebutuhan perangkat kerasnya.

7. Implementasi

Tahap ini kana melakukan pengimplemantasian sistem pada Puskesmas Sunagai Sembilan untuk mendapatkan hasil sesaui dengan harapan.

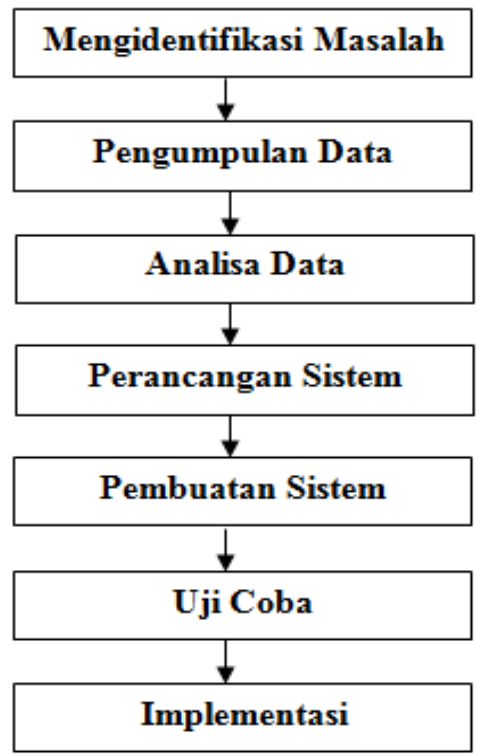

Gambar 1. Kerangk penelitian

\section{HASIL DAN PEMBAHASAN}

\section{a. Context Diagram}

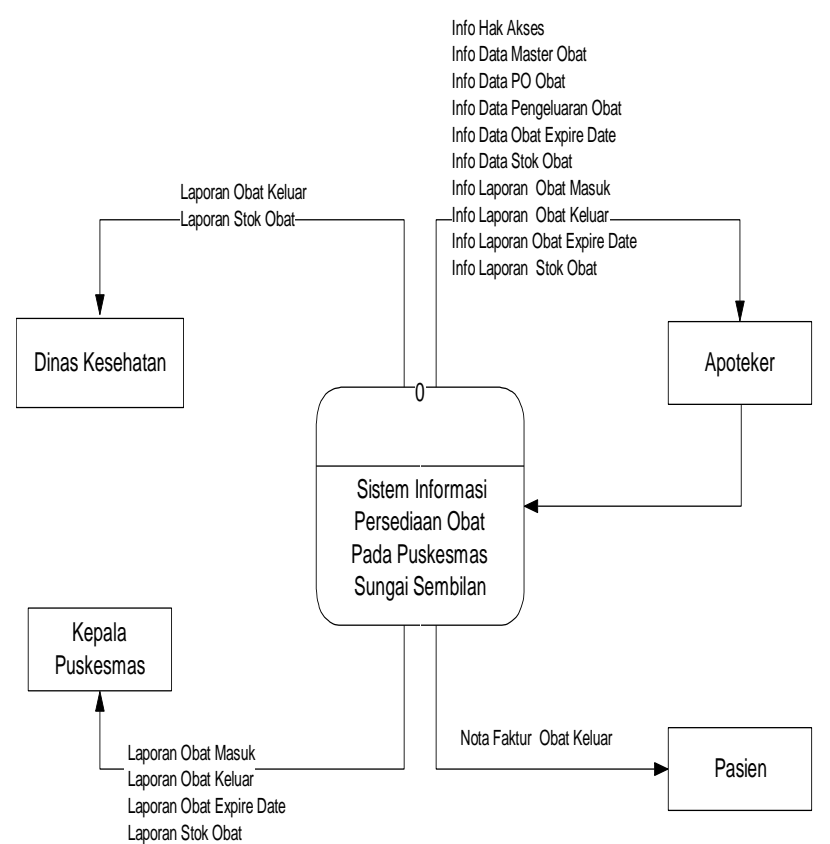

Gambar 2. Context Diagram 
IN F ORMA T I K A

Jurnal Informatika, Manajemen dan Komputer, Vol. 12 No. 1, Mei 2020

elSSN : 2580-3042

pISSN : 1979-0694

\section{b. Data Flow Diagram}

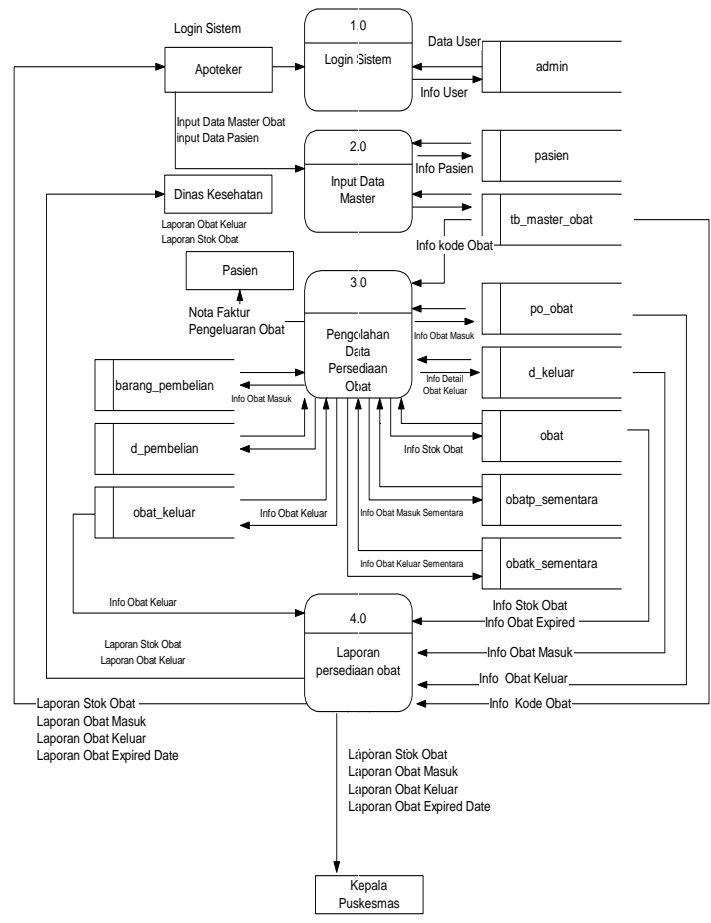

Gambar 3. Data Flow Diagram

\section{c. Implementasi sistem}

\section{Form Menu Utama}

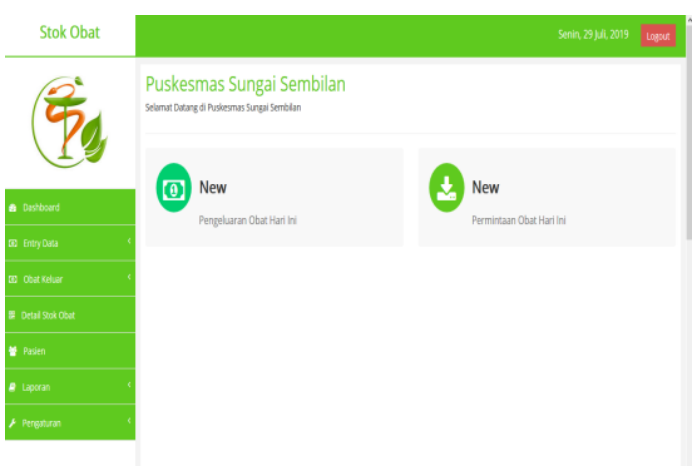

Gambar 4. Form Menu Utama

Form ini menyediakan Menu dashboard yaitu untuk menampilkan tampilan awal Sistem Informasi Persediaan Obat, Menu Entry Data yang terdiri dari (Master kode obat, tambah stok obat, cek obat, obat PO), Menu Obat Keluar yang terdiri dari (data obat keluar, tambah data), Menu Detail Stok Obat untuk melihat stok obat yang tersedia, Menu Pasien untuk menginputkan data pasien, Menu laporan yang terdiri dari Laporan (laporan obat keluar, laporan data, Menu
Pengaturan dan terakhir menu Logout untuk keluar dari aplikasi.

\section{Form Master Obat}

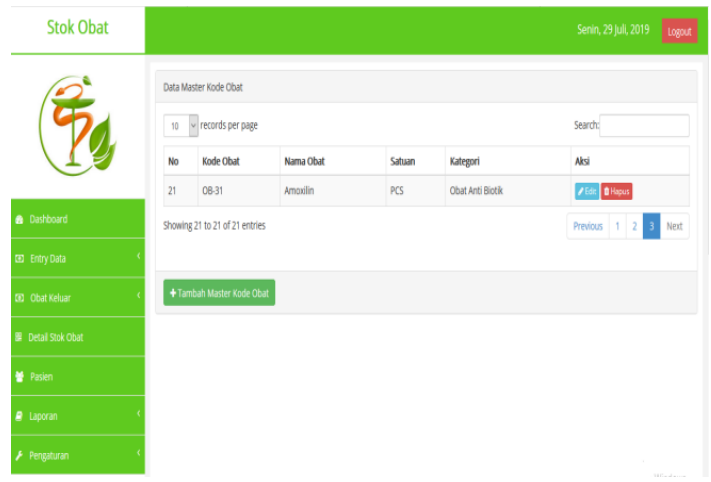

Gambar 5. Form Data Master Obat

Form ini akan menampilkan data obat yang terdaftar di dalam sistem informasi persediaan obat .

\section{Form Tambah Stok}

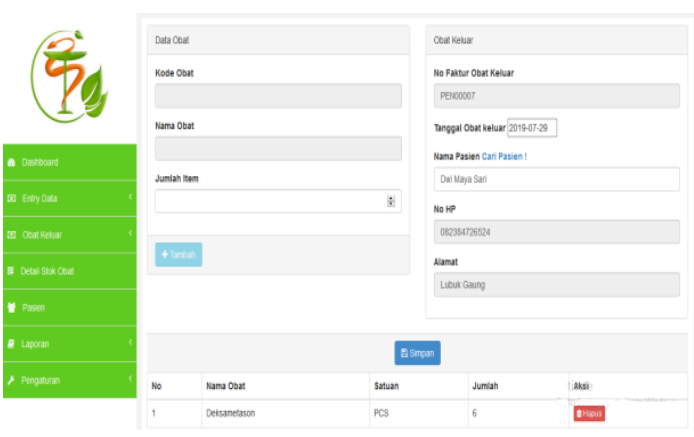

Gambar 6. Form Tambah Stok

Form ini digunakan untuk menambah data obat yang diterima dari dinas kesehatan.

\section{Form Obat Keluar}

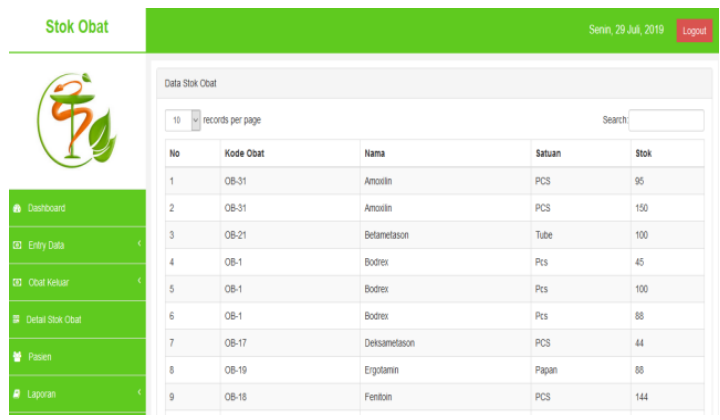

Gambar 7. Form Tambah Obat Keluar 
INFORM TIK

Jurnal Informatika, Manajemen dan Komputer, Vol. 12 No. 1, Mei 2020

eISSN : 2580-3042

pISSN : 1979-0694

Form ini digunakan untuk menambah data obat yang akan dikeluarkan untuk pasien berdasarkan resep dari dokter.

\section{Detail Stok Obat}

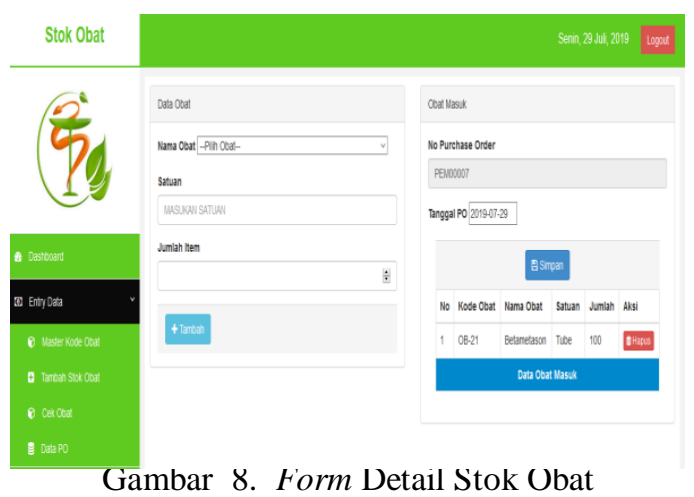

\section{Menu Data Pasien}

Form ini menampilkan data pasien yang terdaftar di dalam sistem.

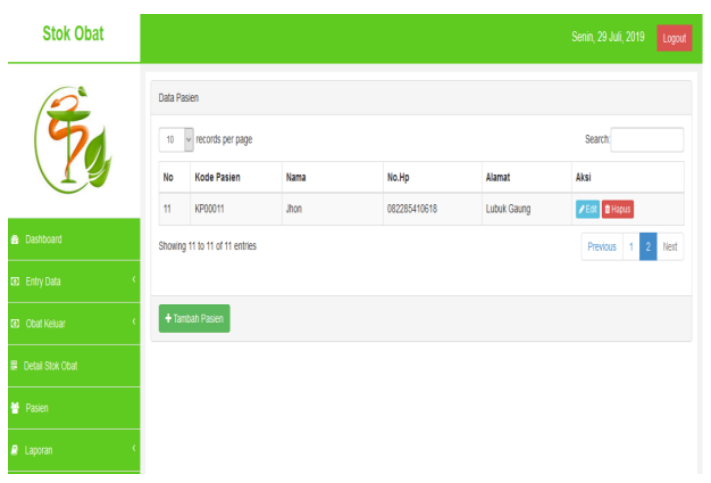

Gambar 9. Form Data Pasien

\section{Data PO}

Form ini berisi data-data obat yang masuk yang diterima dari dinas kesehatan melalui transaksi di form tambah stok obat.

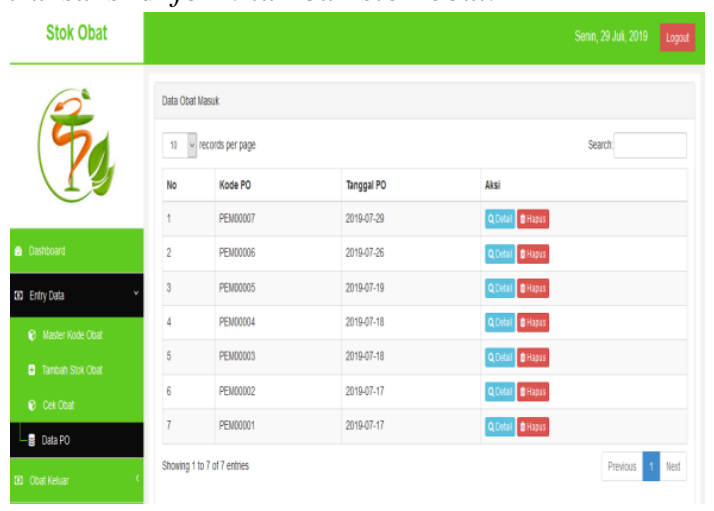

Gambar 10. Form Data Po

\section{Data Obat Keluar}

Form ini berisi data obat keluar yang diberikan kepada pasien berdasarkan resep dokter yang ditebus oleh pasien melalui transaksi di form tambah data obat keluar.

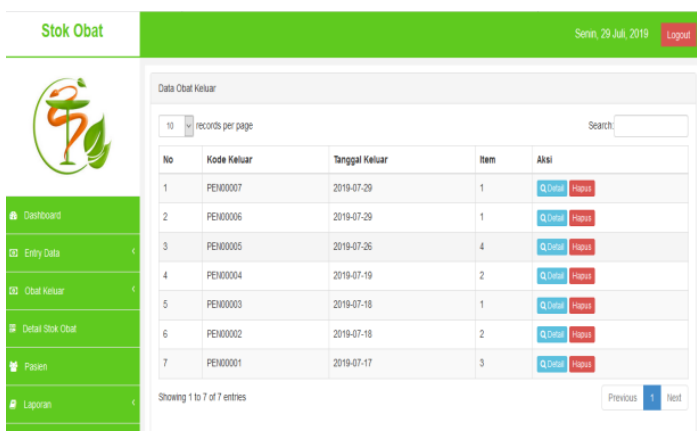

Gambar 11. Form Data Obat Keluar

\section{Laporan Obat Masuk \& Keluar}

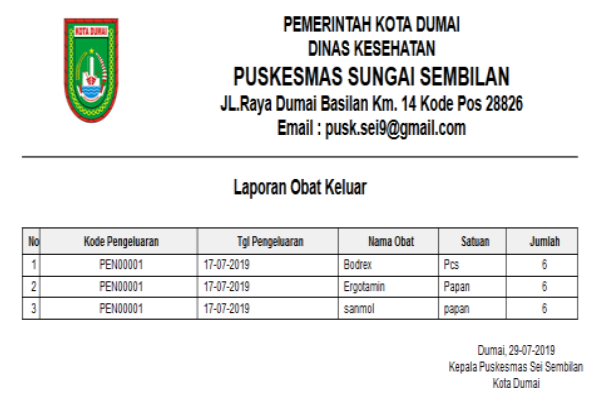

tat Elah Worat Etendi
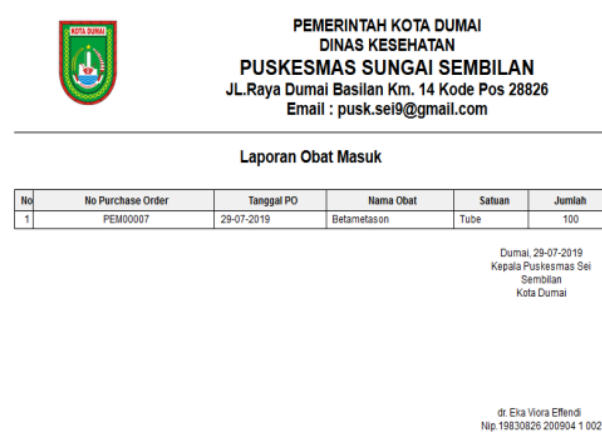

Gambar 12. Laporan Obat Masuk 
IN F ORMA T I K A

Jurnal Informatika, Manajemen dan Komputer, Vol. 12 No. 1, Mei 2020

eISSN : 2580-3042

pISSN : 1979-0694

Laporan Obat kadaluarsa \& Stok Obat

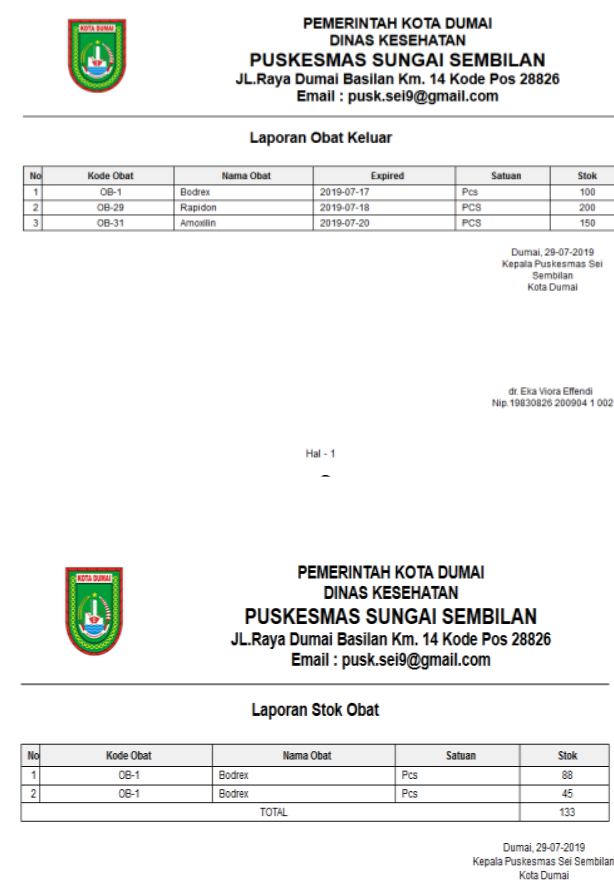

Gambar 13. Laporan Stok Obat

\section{KESIMPULAN}

Berdasarkan hasil penelitian dan pegujian yang telah dilakukan, maka dapat disimpulkan beberapa kesimpulan sebagai berikut :

1. Sistem informasi persediaan obat ini memudahkan bagian apotek puskesmas sungai sembilan dalam melakukan pencatatan obat masuk dan obat keluar.

2. Sistem informasi persediaan obat ini Memudahkan apoteker dalam melakukan pencarian data stok obat untuk melihat ketersediaan obat.

3. Sistem ini memudahkan apoteker dalam membuat laporan persediaan obat yang terstruktur.

4. Sistem ini memberikan informasi obat kadaluarsa yang diketahui dari laporan obat kadaluarsa yang telah divalidasi oleh sistem.

\section{REFERENSI}

Andi. (2014). Sistem Informasi Penjualan Online Tugas Akhir PHP \& MySQL. Yogyakarta: CV. Andi Offset.

Ariani, A. P. (2016). Dasar-Dasar Farmakologi. Yogyakarta: Nuha Medika.

Dahlan, M. (2013). Membuat Web PHP. Yogyakarta: Mitra Utama.

Destiningrum, M., \& Adrian, Q. J. (2017). Sistem Informasi Penjadwalan Dokter Berbassis Web Dengan Menggunakan Framework Codeigniter (Studi Kasus: Rumah Sakit Yukum Medical Centre). Jurnal Teknoinfo, 11(2), 30-37.

Elisawati, E., \& Rianto Riduan S, M. H. (2019). Sistem Inventory Suku Cadang Sepeda Motor Untuk Menghitung Estimasi Stok Menggunakan Metode Economic Order Quantity (Studi Kasus: Pt. Suzuki Rjc Ombak). I N F O R M a T I K a, 8(2), 1. https://doi.org/10.36723/juri.v8i2.118

Fanny A, \& Eko B S. (2015). Pengembangan Sistem Informasi Pengolahan Data Pencari Kerja Pada Dinas Sosial Dan Tenaga Kerja Kota Padang. Jurnal Ilmiah Komputer dan Informatika, 4(2), 93-98, Retrieved from https://ojs.unikom.ac.id/index.php/komputa /article/view/2431

Ignas. (2014). Sistem Inforamasi Penjualan Online Untuk Tugas Akhir. Yogyakarta: CV. Andi Offset.

Jogiyanto, H. (2001). Analisa dan Desain Sistem. Yogyakarta: CV. Andi Offset.

Kaban, R. (2019). Bootstrap, CSS, Framework. Yogyakarta: CV. Andi Offset.

Kadir, A. (2003). Pengenalan sistem informasi. Yogyakarta: CV. Andi Offset.

Sutabri, T. (2012). Analisis Sistem Informasi. Yogyakarta: CV. Andi Offset. 